TITLE:

\title{
Bone-bonding properties of $\mathrm{Ti}$ metal subjected to acid and heat treatments(Abstract_要旨 )
}

$\operatorname{AUTHOR}(S)$ :

Kawai, Toshiyuki

\section{CITATION:}

Kawai, Toshiyuki. Bone-bonding properties of Ti metal subjected to acid and heat treatments. 京都大学, 2013, 博士(医学)

ISSUE DATE:

2013-03-25

URL:

http://hdl.handle.net/2433/174787

RIGHT: 


\begin{tabular}{|l|l|c|c|}
\hline 京都大学 & 博士 (医学) & 氏 名 & 河井 利之 \\
\hline & Bone-bonding properties of Ti metal subjected to acid and heat treatments \\
論文題目 & (酸処理、加熱処理を行ったチタン金属の骨結合特性)
\end{tabular}

\section{（論文内容の要旨）}

チタン金属及びその合金は、優れた機械的強度と生体親和性を有し、広く臨 床応用されている。チタン金属はそのままでは骨と結合する性質（生体活性） を持たないため、様々な方法で生体活性能を付与する方法が開発されてきた。 生体活性能は体液と類似の組成を有する擬似体液内でのアパタイト形成能とよ く相関することが明らかになっている。チタン金属にアパタイト形成能が付与 されるメカニズムには不明な点が多いが、表面形状、結晶構造だけでなく材料 表面の電位特性の関与が明らかになっている。本研究では化学処理と加熱処理 を組み合わせることで、さまざまな表面特性を有するチタン金属を作成し、形 状、結晶構造及び電位特性が、アパタイト形成能や生体内での骨結合能に与え る影響について調査した。

材料: 厚さ $2 \mathrm{~mm} 、 15 \times 10 \mathrm{~mm}$ のチタンプレートに対し、以下の処理を行った。 (1)未処理 (2)加熱処理 (600 度、1 時間) の夕 (3)混酸 (66.3\% $\mathrm{H}_{2} \mathrm{SO}_{4}+10.6 \%$ $\mathrm{HCl}(\mathrm{w} / \mathrm{w}) 、 1$ 時間)処理のみ(4)混酸、加熱処理(5)アルカリ処理 $(5 \mathrm{M} \mathrm{NaOH} 、 24$ 時間) 、希塩酸処理 $(0.5 \mathrm{mM} \mathrm{HCl} 、 30$ 分)、加熱処理(6)アルカリ処理、塩酸処理 $(50 \mathrm{mM} \mathrm{HCl} 、 30$ 分)、加熱処理。方法 : 材料評価として各試料について、走査 型電子顕微鏡（SEM）観察、X線回折（XRD）評価、擬似体液内でのアパタイ 卜形成能評価、ゼータ電位測定を行った。動物実験では、日本白色家兔の両側 脛骨近位骨幹端部に $2 \times 15 \mathrm{~mm}$ の骨孔を作成し、プレートを挿入。術後 $4 、 8$ 、 16、26 週で骨とともに摘出し、引きはがし試験及び組織学的観察（光学顕微鏡 及びSEM）を行った。

結果：SEM による各処理後の材料表面観察では処理 (1)（未処理）及び処理 (2) (加熱処理のみ) では研磨後のスムーズ表面構造が認められたのに対し、処 理(3)（混酸処理）と処理(4)（混酸加熱処理）ではマイクロサイズの凹凸構造の 形成が認められた。アルカリ処理群（処理(5)(6)）ではともにナノサイズの羽毛 状構造が形成されていた。XRDによる結晶構造評価では、加熱処理を行った群 (処理(2)(4)(5)(6) ではルチル相が検出されたが、加熱処理を行わなかった群 (処 理(1) (3)）ではルチル相は検出されなかった。ゼータ電位は酸処理と加熱処理を 併用した群（処理(4)(5)(6)）で正電荷であった。擬似体液に浸漬すると正電荷を 有していた上記 3 群のみで材料表面にアパタイトが形成された。動物実験では、 処理(4)（混酸加熱処理）が他の群に比べて有意に高い引きはがし強度を示し、 組織観察にてプレートと骨の直接結合が確認できた。処理(1)（未処理）と処理 (2)（加熱処理のみ）では骨結合能に有意な差は無く、またアルカリ処理群（処 理(5)(6)）の間にも骨結合能の有意な差は無かった。

考察：未処理群と加熱群の比較からは、結晶構造はアパタイト形成能や骨結 合能には関与しないことが示唆された。混酸処理と混酸加熱処理の比較から、 正電荷がアパタイト形成能や骨結合能に大きく影響したことが示唆された。ア ルカリ処理群においても、酸処理と加熱処理を行うことで正電荷となって高い
アパタイト形成能が付与されたが、骨結合能は混酸加熱処理に劣っていた。こ れは、アルカリ処理群のナノサイズの羽毛状構造は、混酸加熱処理群のマイク ロサイズの凹凸構造に比較すると脆弱であることによると考えられた。本研究 は、表面電位特性がチタン金属の生体活性に大きな影響を与えること、簡便な 酸加熱処理によりチタン金属の骨結合能を大きく高められることを明らかにし たものであり、今後の整形外科分野におけるチタン製インプラント開発に大き く寄与するものである。

(論文審査の結果の要旨)

本研究ではチタン（Ti）金属の表面特性と骨結合能の関係を明らかにするため、化学処 理と加熱処理を組み合わせ様々な表面特性を有するTiプレートを作成し、日本白色家兔 脛骨内での骨結合能を評価した。混酸処理Tiプレートと混酸加熱処理Tiプレートの 比較では、表面構造は両者ともマイクロレベルの微細構造であったが、後者の みで表面正電荷、ルチル型 $\mathrm{TiO}_{2}$ 層、擬似体液内でのアパタイト形成能を有し、 有意に高い骨結合能を認めた。加熱処理のみの $\mathrm{Ti}$ プレートはルチル型 $\mathrm{TiO}_{2}$ 層を 有していたがアパタイト形成能が無く、骨結合能も有意に低かった。アルカリ 処理後に塩酸加熱処理を行ったTiプレートは、表面構造はナノレベルの微細構 造で、表面正電荷、ルチル型 $\mathrm{TiO}_{2}$ 層、アパタイト形成能も認めたが、処理層の 脆弱性のため骨結合能は混酸加熱処理Tiプレートに劣っていた。以上のことか らアパタイト形成能には表面正電荷が大きく関与すること、骨結合能には表面 正電荷とアパタイト形成能だけでなく処理層の強度も重要であることが示唆さ れた。

以上の研究は、チタン金属表面性状と骨結合能の関係を解明し、今後の整形 外科分野におけるチタン製デバイス開発に大きく寄与するものである。

したがって、本論文溥士 (医学) の学位論文として価值あるものと認める。

なお、本学位授与申請者は、平成 25 年 2 月 6 日実施の論文内容とそれに関連した 試問を受け、合格と認められたものである。
要旨公開可能日： 年 月 $\quad$ 日 以降 